\title{
Thermal and Permeability Properties of Metal Aluminum Foams for Functional Applications'
}

Propiedades térmicas y de permeabilidad de espumas metálicas base aluminio para aplicaciones funcionales ${ }^{2}$

\author{
Patricia Fernández-Morales ${ }^{3}$ \\ Carlos Alberto Cano-Montoya ${ }^{4}$ \\ Jesús Alberto Pérez-Mesa \\ María Ángeles Navacerrada
}

doi: 10.11144/Javeriana.iyu21-1.tppm

How to cite this article:

P. Fernández-Morales, C. A. Cano-Montoya, J. A. Pérez-Mesa, and M. A. Navacerrada, "Thermal and permeability properties of metal aluminum foams for functional applications," Ing. Univ., vol. 21, no. 1, pp. 115-130, 2017. http://dx.doi. org/10.11144/ Javeriana.iyu21-1.tppm

\footnotetext{
'Scientific and technological research article. Submitted on: June $30^{\text {th }}, 2016$. Accepted on: November $21^{\text {st }}, 2016$. This article is derived from a research project called "Ecofibras for use in acoustic applications", funded by CIDI-UPB, code 310B-10 / 14-18.. ${ }^{2}$ Artículo de investigación científica y tecnológica. Fecha de recepción: 30 de junio de 2016. Fecha de aceptación: 21 de noviembre de 2016. Este artículo se deriva de un proyecto de investigación denominado Ecofibras para uso en aplicaciones acústicas, financiado por el CIDI-UPB, Radicado 310B-10/14-18. Desarrollado por el grupo de investigación GINUMA de la Universidad Pontificia Bolivariana, Medellín, Colombia.

${ }^{3}$ Metallurgical engineer, Universidad de Antioquia, Medellín, Colombia. Master in engineering, Universidad Pontificia Bolivariana, Medellín, Colombia. Doctor in engineering, Universidad Pontificia Bolivariana. Professor, School of Engineering, Universidad Pontificia Bolivariana. E-mail: patricia.fernandez@upb.edu.co.

${ }^{4}$ Mechanical engineer, Universidad Nacional de Colombia. Master in engineering, Universidad Pontificia Bolivariana, Medellín, Colombia. Engineer, Endicontrol, Medellín, Colombia. E-mail: carlos.cano@endicontrol.com.

${ }^{5}$ Mechanical engineer, Universidad EAFIT, Medellín, Colombia. Graduate studies in Economics, Universidad de los Andes, Bogotá, Colombia. Master in engineering, Universidad EAFIT, Medellín, Colombia. Full-time faculty of Civil Engineering, Universidad EAFIT. E-mail: iperez@eafit.edu.co.

${ }^{6}$ Bachelor and PhD in Physics from Universidad Complutense. Currently works at the Department of Structures an Physics at the Escuela Técnica Superior de Arquitectura at Universidad Politécnica de Madrid. E-mail: mdelosangeles. navacerrada@upm.es.
} 


\section{Abstract}

Objective: to determine the coefficients of permeability and thermal conductivity of aluminum metal foams, thermal transference and pressure drop tests were carried out. Methods: metal foam samples measuring $50 \mathrm{~mm}$ in diameter and $20 \mathrm{~mm}$ in thickness with pore sizes ranging between 0.5 and $2.0 \mathrm{~mm}$ were used for both tests. An adaptation in a fluid flow system was made to perform the pressure drop tests, and Darcy's law was used to calculate the permeability values. A thermal box test and Fourier's law were used to obtain the conductivity coefficients. Results: the results showed that the pore size has an important influence on the values of permeability and thermal conductivity. Finally, the results were compared with those reported by other researchers and were found to be consistent with those found in previous work. Conclusions: our interest is to enhance knowledge regarding aluminum metal foams and show their potential use in applications that involve fluid flow and heat transfer.

\section{Keywords}

Aluminum; foams; permeability; thermal conductivity

\section{Resumen}

Objetivo: se hicieron pruebas de transferencia térmica y de caída de presión para determinar los coeficientes de permeabilidad y de conductividad térmica de espumas metálicas de aluminio fabricadas mediante el proceso IPS (Infiltración de Preformas Solubles). Método: para ambas pruebas, se utilizaron muestras de espumas metálicas con $50 \mathrm{~mm}$ de diámetro y $20 \mathrm{~mm}$ de espesor, con tamaños de poro de $0.5,1.0$ y $2.0 \mathrm{~mm}$ y una densidad relativa de 0.34 . Para la realización de las pruebas de caída de presión, se realizó una adaptación de un sistema de flujo de fluidos y, los valores de permeabilidad se calcularon utilizando la ley de Darcy. Por otra parte, para obtener los coeficientes de conductividad se utilizó el ensayo de la caja térmica y la ley de Fourier. Resultados: se encontró que hay una influencia importante del tamaño de los poros en los valores de permeabilidad y de conductividad térmica obtenidos. Por último, los resultados se compararon con los obtenidos por otros investigadores, determinando que estos son muy consistentes con los encontrados en el presente trabajo. Conclusiones: nuestro interés es mejorar el conocimiento sobre las espumas metálicas y en este sentido, proponer la posibilidad de su uso en aplicaciones que involucran flujo de fluidos y transferencia de calor.

\section{Palabras clave}

Aluminio; espumas; permeabilidad; conductividad térmica 


\section{Introduction}

Cellular metals are a family of materials characterized by a gaseous structure in a solid metal, producing a highly porous material. There are two types of cellular metals, i.e., closed cell metallic foams, which are distinguished by thin walls around the pores, and open cell metallic foams, which are characterized by interconnected pores. In addition to the low density of these materials, both groups of cellular metals present interesting physical and mechanical properties. These properties include high rigidity, shock absorption, high resistance to compression, deformation energy absorption, good acoustic absorption and fluid flow permeability, among others. Depending on the type of cell structure, it is possible to determine its potential structural and functional application [1]-[3].

Specifically, open cell metallic foams have a wide spectrum of functional applications due to their characteristics, including tortuosity and high surface to volume ratio, which favor the mixture of fluids and the turbulent regimen, producing an excellent thermal transference. Thus, it is possible to consider the flow of liquids and gasses through the foam, which, in applications such as heat exchangers, favors the exchange of heat between the fluid and the solid metal [4]-[6]. Alternatively, open cell metal foams can also be used to act on the fluid as a filter, mixer, electrode or catalyst [7] in applications in which permeability is relevant, such as filters, diffusers and catalyst supports. In the case of filter design, if the material must last for at least 1000 hours of use, it is necessary to consider variables, such as low pressure conditions (less than $5 \mathrm{kPa}$ ), mechanical resistance (not less than $5 \mathrm{MPa}$ ), corrosion resistance and thermal resistance [8]. The resistance of the fluid through the porous material of the filter is another important parameter. Sometimes, a high resistance to the fluid can be beneficial in the case of catalysis or heat transference [9]. All the aforementioned qualities can be found in cellular metals in addition to their low density.

A few years ago, polymers began entering this field with new products based on metallic foams in a category similar to filters. This field includes diffusers, 
air injectors, micro-bubblers, microemulsifiers, elements that permit the purification of water, liquid dispersion, oxygenation and aeration processes, liquid mixture, respirable aerosols for medications and others. In particular, diffusers are elements that are utilized in the aeration and agitation of water processes and treatment, while microemulsifiers produce compounds of immiscible liquids by means of the agitation of micro-bubbles. The use of these two elements is principally found in the cosmetic and pharmaceutical industry and the treatment of water and foods [10], [11].

The transformation of products by means of chemical reactions generally implies a catalysis process or the combined capacity of thermal and mass transference. To obtain an appropriate and effective reaction, it is crucial to ensure an adequate surface area interface between the catalyst and the gas or liquid reactant. Hence, if catalysis is processed in a structure that is too highly porous to act as a support, the reaction would have a large surface area for greater effectiveness [12]. This increase is much more interesting in the case of multifunctional fuel processors [13] in which metallic foams may have a role to play in the thermal management of PEMFC (Polymer Electrolyte Membrane Fuel Cells) [14]. Along the same lines, the use of open cell foams as inserts in tubular reactors [15] and vapor pre-concentrators for thermal desorption in gas mixtures [16] are innovative alternatives given their excellent heat and mass transference. Even though ceramic materials have been used thus far, open pore cellular metals could potentially replace these materials and provide additional benefits, including high ductility and thermal conductivity [1].

The following three principles are important in the use of interconnected pore metals in heat exchangers: i) high conductivity struts (cell borders) that are highly conductive, preferably metals such as copper or aluminum, ii) a turbulent flow to facilitate local transference of the solid surface heat to the fluid [17] and, iii) low pressure between the input and output, forcing the fluid out of the medium with a moderate strength pumping system [18]-[21]. There is a growing demand for compact, strong and lightweight systems for heat transfer removal devices that are focused on open porosity metal foams as the ideal candidates [22]-[24]. In thermal transference, there are other interesting applications, such as heat sinks for electronic systems, radiators with high efficiency receptors of solar energy and multilayer heat exchangers [25]-[28]. The following investigation will describe the tests performed on aluminum foams with three different pore sizes to analyze the material's permeability and thermal conductivity and determine its suitability for use in the aforementioned applications. 


\section{Materials and Methods}

\subsection{Production of metal foams}

Metallic foams of an aluminum A356 alloy with open and interconnected pores, whose chemical composition was based on a content of Si between 4.5-6.5\% and $\mathrm{Mg}$ between 0.2-0.45\%, were produced. The process used is known as Infiltration of Soluble Preforms (ISP) and consists of the following three main stages: i) preparation of the soluble preform (in this case, $\mathrm{NaCl}$ was used), ii) melting of the metal and, iii) infiltration by means of vacuum pressure. The resulting foams were machined to the diameter and thickness necessary for the tests. In general, the samples had a relative average density of 0.34 , which refers to the relationship between the foam density and the bulk density of the metallic matrix material $\left(\rho / \rho_{s}\right)$. Additionally, the relative density is complementary to the porosity percentage. For the present study, the porosity was approximately $66 \%$, and the foam density was approximately $0.92 \mathrm{gcm}^{-3}$.

It is important to note that the ISP process used to obtain the metallic foam with open porosity allows for controlling the required pore size and its morphology by means of the selection of the appropriate preform. The same is true with regards to the density, which is controlled by means of the compacting of the preform. In this case, the $\mathrm{NaCl}$ used was sifted to the particle size necessary to achieve the desired effects in pore size. The relative density of the foam is typical of preforms without previous compaction. Compared to the other processes available for producing open cell foam, the ISP process achieves porosities between 55 to $98 \%$, while the other processes, such as replication casting and vapor deposition on polymer foams, can achieve porosities of $80-98 \%$ [2]-[3].

\subsection{Permeability}

Aluminum foam specimens $50 \mathrm{~mm}$ in diameter and $20 \mathrm{~mm}$ in thickness (see Figure 1) with pore sizes of $0.5,1.0$ and $2.0 \mathrm{~mm}$ were used for the tests in this study. An modification was made to a flow system in the fluids laboratory. The flow system had an apparatus to hold the foam (a transparent glass tube with pressure transductors on both ends), a Valtek's Flowserve Corporation servo-valve with a capacity of $90 \pm 1 \mathrm{psi}$, an $O M E G A$ flow meter with an interval of $0-$ 1000 pie. $\mathrm{min}^{-1}$ and a precision level of $1 \%$, and a PC with Labview software to recompile the data. Figure 2 shows the detail of the apparatus to hold the metallic foam in the system, allowing for direct observation throughout the trial. All necessary precautions were taken to assure a nearly perfect fit between the 
foam and the internal surface of the tube to prevent leakage along the borders of the sample which would distort the data.

Figure 1. Samples for the permeability test

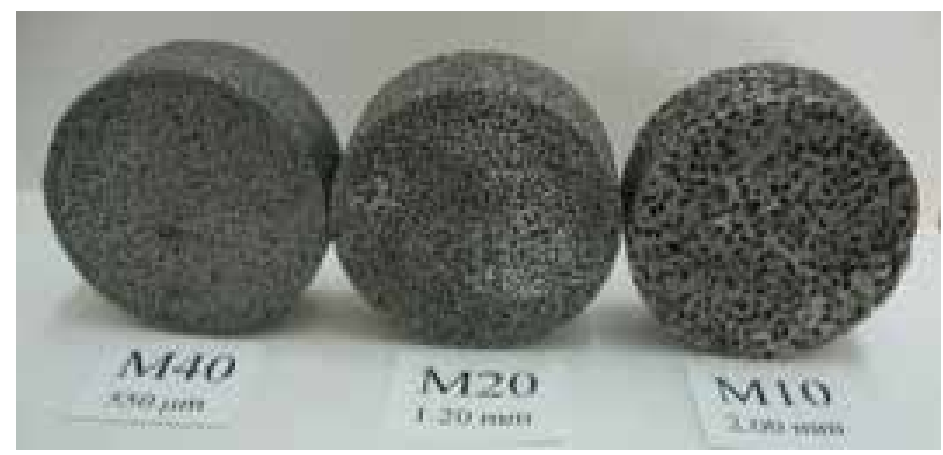

Source: authors' own elaboration

Figure 2. Flow system adapted for the permeability test

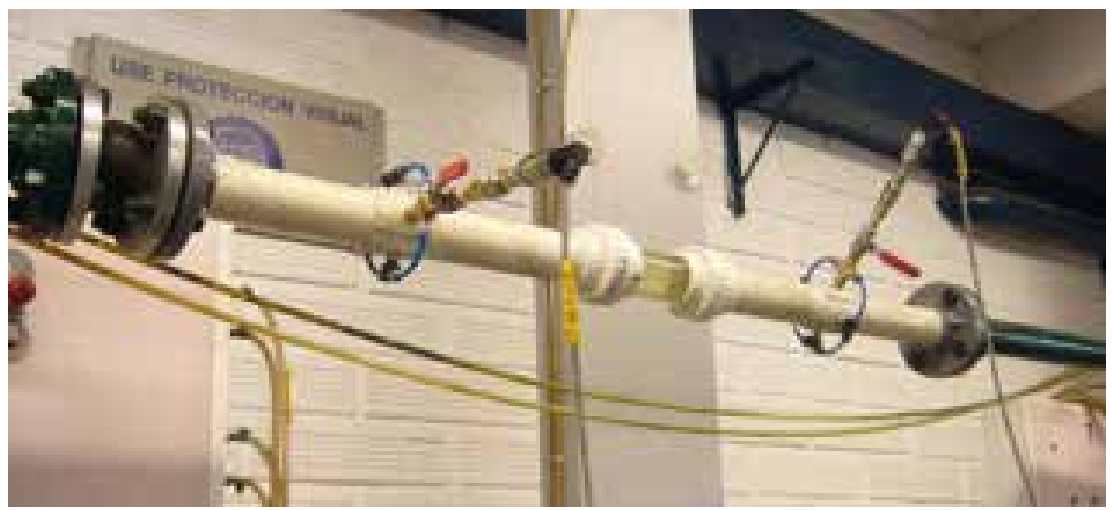

Source: authors' own elaboration

The permeability of the fluid through the porous material was experimentally determined by passing a fluid with known viscosity, in this case water, through the material and measuring both the pressure drop and the velocity of volumetric flow after passing through the material. The permeability values were obtained using the modified Darcy law [7]-[8], [29], and thus the porous mediums and the fluid properties must be considered:

$$
\frac{Q}{A}=q=\frac{K}{\mu}\left(\frac{P_{e}-P_{s}}{L}\right)
$$


$Q$ is volumetric flow $\left[\mathrm{m}^{3} \mathrm{~s}^{-1}\right], A$ is the transversal section of the sample $\left[\mathrm{m}^{2}\right]$, $q$ is the apparent flow velocity (equal to the surface velocity $\left.v_{0}\right)\left[\mathrm{ms}^{-1}\right], K$ is the permeability $\left[\mathrm{m}^{2}\right], \mu$ is the dynamic viscosity of the fluid $[\mathrm{Pa} . \mathrm{s}], P_{e}$ is input fluid pressure, $P_{s}$ is the output pressure (both are manometric) and $L$ is the thickness of the sample $[\mathrm{m}]$. The theoretic dynamic viscosity of water was as follows: $\mu=1.002 \times 10^{-3}$ [Pa.s $]$ at $20^{\circ} \mathrm{C}$.

The permeability of the fluid flow in the aluminum foam under investigation was determined by the permanent flow of water through the samples located in the system described in Figure 2. The fluid pressure regulation was generated by the servo-valves and before beginning the pressure drop on the sample foams, the measurements corresponding to the losses were taken. For the pressure measurements $P_{e}$ y $P_{s}$, we installed transductors for manometric pressure measurements at the input and output of the sample. The data were collected at one-second intervals using Labview software. There were 10 tests for each experiment, and the minimum squared method was used to adjust the curves.

\subsection{Heat transference}

To measure the thermal conductivity of each one of the foams, a highly insulated thermal box with a removable lid was used, as is shown in Figure 3. It was composed of walls with square openings for the material whose thermal conductivity was being tested, and the lid and the base of the box were insulated with polystyrene foam sheets measuring $5 \mathrm{~cm}$ thick. Inside the thermal box there was a black box with a $100 \mathrm{~W}$ light bulb used to reduce the effects of radiation heating because we were only studying the processes of convection and conduction. The light bulb was used to elevate the temperature in the interior of the box to approximately $50^{\circ} \mathrm{C}$. The interior temperature was controlled by an exterior thermal regulator connected to the interior by means of a thermal sensor on the black box.

Four thermocouples, two placed in the interior before closing the thermal box and two placed in the exterior, measured the temperatures of the air inside the box, the temperature of the internal and external walls of the aluminum foam, and the air outside the box. The heat increased gradually up to $50^{\circ} \mathrm{C}$ and afterwards it took approximately three hours to reach a stationary state. It should be noted that even though this method did not exactly follow a standard protocol specification, it is a method that showed a level of uncertainty of less than $10 \%$. In addition, the test condition in which the box was located 
was highly controlled such that ambient temperature and humidity did not influence the results. Nevertheless, ambient temperature measurements were taken as a reference.

Figure 3. Equipment to measure the thermal conductivity coefficient

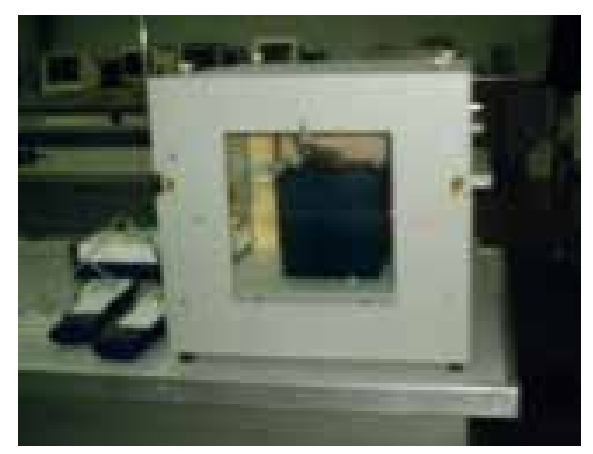

Source: authors' own elaboration

The heat exchange through the material layer could be a result of the following three possible mechanisms: conduction, convection and radiation. In the case of the homogenous material slide and with a thickness of less than $5 \mathrm{~cm}$ and at moderate temperatures the thermal energy flow is mainly the result of the phenomena of convection and conduction given by the Fourier law. In a stationary state and considering the unidirectional flow, the resulting formulas are [30]:

- Interior air-wall convection:

$\Phi=h_{\text {int }} \cdot S \cdot\left(t_{1}-t_{2}\right)$

$b_{\text {int }}$ being the coefficient of interior air convection, $t_{1}$ the temperature of the interior air and $t_{2}$ the temperature of the interior material wall.

- Conduction through the wall:

$\Phi=k \cdot S \cdot \frac{\left(t_{2}-t_{3}\right)}{d}$

$k$ being the material thermal conductivity and $t_{3}$ the temperature of the exterior material wall. 
- Exterior air-wall convection:

$\Phi=h_{\text {ext }} \cdot S \cdot\left(t_{3}-t_{4}\right)$

$b_{\text {ext }}$ being the convection coefficient of the exterior air and $t_{4}$ the exterior air temperature.

By means of these three equations and the experimental measurements of the temperatures, the thermal conductivity of the material under study, $k$, can be determined. For the sake of calculations, the interior and exterior convection coefficient for the air is given the value of approximately 8.1 $\mathrm{W} . \mathrm{K}^{-1} \cdot \mathrm{m}^{-2}$, as recommended by the manufacturer of the equipment. Following equations 2 and 4 , the experimental value of $\Phi S^{-1}$ was determined. Once $\Phi S^{-1}$ is clarified, k can be calculated using equation 3.

\section{Results}

\subsection{Permeability}

Table 1 presents the results of the average pressure drops obtained:

Table 1. Permeability values obtained

\begin{tabular}{|c|c|c|}
\hline $\begin{array}{c}\text { Pore size } \\
{[\mathrm{mm}]}\end{array}$ & $\begin{array}{c}\text { Porosity } \\
{[\%]}\end{array}$ & Permeability $(\mathrm{K})\left[\mathrm{m}^{2}\right]$ \\
\hline 0.5 & 63.3 & $1.76 \times 10^{-10}$ \\
\hline 1.0 & 65.9 & $1.84 \times 10^{-10}$ \\
\hline 2.0 & 67.6 & $2.36 \times 10^{-10}$ \\
\hline
\end{tabular}

Source: author's own elaboration

The results show that there is a direct, albeit not proportional, relationship between the pore size and the permeability obtained. This means that a larger pore diameter indicates an increase in permeability. This increase grows roughly exponentially in relation to the increase in pore size due to the reduction in barriers to the fluid's movement, flowing freely and with less resistance through the foam. The increase in permeability reaches $5 \%$ for the pore sizes between $0.5 \mathrm{~mm}$ to $1.0 \mathrm{~mm}$, while for pores between $0.5 \mathrm{~mm}$ to $2.0 \mathrm{~mm}$ the increase in permeability reaches $34 \%$. The permeability increases $29 \%$ with pore sizes between $1.0 \mathrm{~mm}$ to $2.0 \mathrm{~mm}$. Similarly, a proportional inverse relationship between 
the relative density and the permeability was estimated, indicating that as the pore size increases, the relative density of the metallic foam decreases. Furthermore, in tests conducted with the same fluid velocities and when comparing foams with pores sizes of $1.45 \mathrm{~mm}$ and $0.45 \mathrm{~mm}$, there is a drastic increase in pressure drops when the pores are significantly smaller [17].

Despois et al. [7] obtained permeability values of $4 \times 10^{-10} \mathrm{~m}^{2}$ in a pressure drop test using aluminum foam with $0.4 \mathrm{~mm}$ pore size. A recent investigation [5] indicates that as porosity increases, the frequency of pressure drops decreases. In other words, permeability increases with the decrease in relative density. The results of this investigation agree with the two mentioned above.

Recently, numeric methods (Finite Elements Method [FEM]) were used to predict the permeability of aluminum foams with $80 \%$ porosity, achieving a permeability value of $7.8 \times 10^{-7} \mathrm{~m}^{2}[31]$. This conforms to the results reported by Ranut $e t$ al. for foams with porosity percentages between $87 \%$ and $98 \%$ [18]. This bolsters the finding that permeability increases as the porosity percentage increases.

\subsection{Heat transference}

Table 2 presents the average thermal conductivity results obtained for the foams of three different pore sizes. The relationship of the data with respect to the pore size can be clearly seen.

Table 2. Average thermal conductivity

\begin{tabular}{ccc}
\hline $\begin{array}{c}\text { Pore size } \\
{[\mathrm{mm}]}\end{array}$ & $\begin{array}{c}\text { Porosity } \\
{[\%]}\end{array}$ & $\begin{array}{c}\text { Thermal Conductivity } \\
\left(\text { W. }^{-1} K^{-1}\right)\end{array}$ \\
\hline $0.5 \mathrm{~mm}$ & 63.3 & 0.6 \\
\hline $1.0 \mathrm{~mm}$ & 65.9 & 1.1 \\
\hline $2.0 \mathrm{~mm}$ & 67.6 & 3.0 \\
\hline
\end{tabular}

Source: author's own elaboration

The average values collected in the three foams demonstrate that as pore size increases, the thermal conductivity also increases. This property is approximately five times greater in $2 \mathrm{~mm}$ foams than in the $0.5 \mathrm{~mm}$ sample. Thermal conductivity is a measure of a combination of the thermal conductivity in the aluminum and the air, and it is possible that the latter was not representative. Furthermore, it should be noted that the heat flow that is transported by con- 
duction in the solid is proportional to the volume fraction of the same solid. The experimental foams have a relatively similar density; however, when the pore size varies, the transversal section of the struts varies as well. The foams with smaller pore sizes have smaller cell borders and thus the heat flow finds greater obstacles, reducing its conductivity.

Studies on the thermal conductivity of metallic foams, such as those performed by Kanaun et al. [32], simulate the phenomenon in aluminum foams with open porosity and metal solid percentages between 2 and $10 \%$, obtaining conductivity values between $1.58 \mathrm{~W} \cdot \mathrm{m}^{-1} \mathrm{~K}^{-1}$ and $6.8 \mathrm{~W} \cdot \mathrm{m}^{-1} \mathrm{~K}^{-1}$, respectively. These values are slightly larger than those collected in the present investigation but support the claim that as the solid percentage increases, the thermal conductivity increases, even though Kanaun et al. did not indicate the pore sizes used. Phanikumar et al. [33] worked with aluminum foams of varying porosities (5 to $40 \mathrm{ppi}$ ) undergoing natural conductivity, resulting in thermal conductivity between $4.4 \mathrm{Wm}^{-1} \mathrm{~K}^{-1}$ and $7.3 \mathrm{~W} \cdot \mathrm{m}^{-1} \mathrm{~K}^{-1}$, and the greater value belonged to the samples with the larger pores. However, these researchers discovered that thermal conductivity increases when the porosity percentage is lower, such that it is necessary to determine if the behavior is associated with the specific conditions during the test. Bianchi et al. [34] reported thermal conductivity findings of $7.7 \mathrm{~W} \cdot \mathrm{m}^{-1} \mathrm{~K}^{-1}$ for foams with $89 \%$ porosity and proved that this is fundamentally due to conductivity because radiation and convection are negligible for high conductivity materials. Under test conditions for heat transference by means of fluids passing through the metallic foam, thermal conductivity increases when the diameter of the cell borders is smaller or the relative density increases. This could be due to the internal surface area depending inversely on the diameter and the transversal section of the heat transference increasing when the relative density increases [35].

Finally, comparing the metallic foams with foams of other materials in applications where they have a potential use, it can be found that the ceramic foams are utilized as supports for catalysis and heat exchangers [36], [37] because they possess qualities, such as chemical stability, mechanical resistance and elevated temperatures $\left(1500^{\circ} \mathrm{C}-2500^{\circ} \mathrm{C}\right)$. Nevertheless, ceramic materials are difficult to produce, are costly and the pore size and pore morphology cannot be controlled, whereas polymer foams, such as metals, can be employed as heat exchangers because they offer various advantages, such as a low density and corrosion resistance, and their only main drawbacks are low thermal conductivity $(0.1$ a 0.3 $\mathrm{W} . \mathrm{m}^{-1} \mathrm{~K}^{-1}$ ) and low mechanical resistance [38]-[40]. 


\section{Conclusions}

The pore size in the metallic foams has a direct influence on its behavior with fluid flows and thermal conductivity. An increase in the size of the pores permits greater permeability. This is important for applications in which pressure decreases should be kept to a minimum. Thus, when these materials are used as filters, the pore size should correspond to the size of the particles to be filtrated. There exists no single pore size that is better than the others, but rather the pore size should be analyzed and optimized for every particular application.

Thermal conductivity increases as the pore size increases. The use of aluminum foam in thermal applications is very promising as it has a large amount of transference. In contrast to the literature, there is a definite influence of the size of the borders of each cell. This effect should be studied in greater detail.

Both the permeability and heat transference of the aluminum foam used in this investigation demonstrate the foam's potential for use in heat exchangers, catalysis supports, electronic cooling systems, and even electrode cooling combustible cells. However, it is necessary to consider that both properties have an inverse behavior with respect to the pore characteristics in the foam and a compromise should be found between these two properties.

\section{Referencias}

[1] J. Banhart, "Manufacture, characterization and application of cellular metals and metal foams”, Prog. Mater. Sci., vol. 46, pp. 559-632, 2001.

[2] M.F. Ashby, A. Evans, N.A. Fleck, L.J. Gibson, J.W. Hutchinson, and H.N.G. Wadley, Metal foams: a design guide, Oxford: Butterworth-Heinemann, 2000.

[3] H.P. Degischer, Handbook of Cellular Materials - Production, Processing, Applications, Eds. H.P. Degischer and B. Kriszt, Weinheim: Wiley-VCH, 2002, pp. 5-7.

[4] W. Azzi, W. L. Roberts, and A. A. Rabiei, "Study on pressure drop and heat transfer in open cell metal foams for jet engine applications", Mat. Design, vol. 28, pp. 569-574, 2007.

[5] G. Ambrosio, N. Bianco, W. K.S. Chiu, M. Iasiello, V. Naso, M. Oliviero, "The effect of open-cell metal foams strut shape on convection heat transfer and pressure drop", Appl. Therm. Eng, no. 103, pp. 333-343, 2016.

[6] K. Hooman, M.R. Malayeri, "Metal foams as gas coolers for exhaust gas recirculation systems subjected to particulate fouling”, Energ. Convers. Manage., vol. 117, pp. 475-481, 2016.

[7] J. F. Despois and A. Mortensen, "Permeability of open-pore microcellular materials", Acta Materialia, vol. 53, pp. 1381-1388, 2005. 
[8] A. Leonov, "Cellular structure for catalysts and filters. Cellular Metals: Manufacture, properties, Applications”, in Proceedings: International Conference on Cellular Metals and Metal Foaming Technology, Berlin, Germany, pp. 47-50, June 2003.

[9] V. P. Rodrigues and M. Innocentini, "Gas permeation through perforated metallic foams", in Proceedings of Porous Metals and Metallic Foams - Metfoam, Montreal, Canada, pp. 463-466, September 2007.

[10] X. Li, G. Liu, M. Shi, D. Zou, Ch. Wang, J. Zheng, "A novel electro-catalytic ozonation process for treating Rhodamine B using mesoflower-structured $\mathrm{TiO} 2$-coated porous titanium gas diffuser anode", Sep. Purif. Technol, vol. 165, pp. 154-159, 2016.

[11] Ch.-H. Huang, Ch.-Sh. Chang, Sh.-H. Chang, Ch.-J. Tsai, T.-Sh. Shih, D.T. Tang, "Use of porous foam as the substrate of an impactor for respirable aerosol sampling", Aerosol Sci., no. 36, pp. 1373-1386, 2005.

[12] S. T. Kolaczkowski, S. Awdrya, T. Smith, D. Thomas, L. Torkuhl, R. Kolvenbach, "Potential for metal foams to act as structured catalyst supports in fixed-bed reactors", Catal. Today, vol. 273, pp. 221-233, 2016.

[13] L. Tianjian, "Ultralight porous metals: from fundamentals to applications", Acta Mech. Sinica (English Series), vol. 18, no. 5, pp. 457-479, October 2002.

[14] M. S. Hossain, and B. Shabani, "Metal foams application to enhance cooling of open cathode polymer electrolyte membrane fuel cells", J Power Sources, vol. 295, pp. 275$291,2015$.

[15] C. Hutter, A. Zenklusen, R. Lang, and Ph. Rudolf von Rohr, "Axial dispersion in metal foams and streamwise-periodic porous media", Chem. Eng. Sci., vol. 66, pp. 1132-1141, 2011.

[16] J. W. Grate, N. C. Anheier, and D. L. Baldwin, "Progressive Thermal Desorption of Vapor Mixtures from a Preconcentrator with a Porous Metal Foam Internal Architecture and Variable Thermal Ramp Rates”, Anal. Chem., no. 77, pp. 1867-1875, 2005.

[17] J. Banhart, "Properties and Applications of Cast Aluminum Sponges", Adv. Eng. Mater., vol. 2, no. 4, pp. 188-191, 2000.

[18] P. Ranut, E. Nobile, and L. Mancini, "High resolution X-ray microtomography-based CFD simulation for the characterization of flow permeability and effective thermal conductivity of aluminum metal foams”. Exp. Therm. Fluid Sci., vol. 67, pp. 30-36, 2015.

[19] X.H. Han, Q. Wang, Y. G. Park, C. T'Joen, A. Sommers, and A. Jacobi, "A review of metal foam and metal matrix composites for heat exchangers and heat sinks", Heat Transf. Eng., vol. 33, pp. 991-1009, 2012.

[20] N. Dukhan, and M. Ali, "Strong wall and transverse size effects on pressure drop of flow through open-cell metal foam”, Int. J. Therm. Sci., vol. 57, pp. 85-91, 2012. 
[21] P. M. Kamath, C. Balaji, and S. P. Venkateshan, "Convection heat transfer from aluminium and copper foams in a vertical channel - an experimental study”, Int. J. Therm. Sci., vol. 64, pp. 1-10, 2013.

[22] K. Boomsma, D. Poulikakos, and F. Zwick, "Metal foams as compact high performance heat exchangers", Mech. Mater., no. 35, pp. 1161-1176, 2003.

[23] C. T'Joen, P. De Jaeger, H. Huisseune, S. Van Herzeele, N. Vorst, and M. De Paepe, "Thermo-hydraulic study of a single row heat exchanger consisting of metal foam covered round tubes", Int. J. Heat Mass Transfer, no. 53, pp. 3262-3274, 2010.

[24] Y. Yao, H. Wu, and Z. Liu, "A new prediction model for the effective thermal conductivity of high porosity open-cell metal foams", Int. J. Therm. Sci., vol. 97, pp. 56-67, 2015.

[25] V. V. Calmidi, and R. L. Mahajan, "Forced convection in high porosity metal foams", J. Heat Transfer, vol. 122, no. 3, pp. 557-565, 2000.

[26] S. Y. Kim, J. W. Paek, and B. H. Kang. "Flow and heat transfer correlations for porous fin in a plate-fin heat exchanger", J. Heat Transfer, vol. 122, no. 3, pp. 572-578, 2000.

[27] A. F. Bastawros, "Effectiveness of open-cell metallic foams for high power electronic cooling", in Thermal Management of Electronics, ASME Proc HTD-361-3/PID-3, pp. 211-217, 1997.

[28] C. Albanakis, D. Missirlis, N. Michailidis, K. Yakinthos, A. Goulas, H. Omar, D. Tsipas, and B. Granier, "Experimental analysis of the pressure drop and heat transfer through metal foams used as volumetric receivers under concentrated solar radiation”, Exp. Therm. Fluid Sci., no. 33, pp. 246-252, 2009.

[29] R. Goodall, J. F. Despois, A. Marmottant, L. Salvo, and A. Mortensen, "The effect of perform processing on replicated aluminium foam structure and mechanical properties", Scripta Mater., vol. 54, pp. 2069-2073, 2006.

[30] S. Amjad, "Thermal conductivity and noise attenuation in aluminium foams", M.S. Thesis. University of Cambridge, Cambridge, 2001.

[31] M. Osorno, H. Steeb, D. Uribe, and O. Ruiz, "Estimation of large domain Al foam permeability by finite difference method", in 84th Annual Meeting of the International Association of Applied Mathematics and Mechanics (GAMM), vol. 13, no. 1, pp. 247-248, December 2013.

[32] S. Kanaun and O. Tkachenko, "Effective conductive properties of open-cell foam", Int. J. Eng. Sci., vol. 46, pp. 551-571, 2008.

[33] M. S. Phanikumar and R. L. Mahajan, "Non-Darcy natural convection in high porosity metal foams", Int. J. Heat Mass. Tran., vol. 45, pp. 3781-3793, 2002.

[34] E. Bianchi, T. Heidig, C. Visconti, G. Groppi, H. Freund, and E. Tronconi, "An appraisal of the heat transfer properties of metallic open-cell foams for strongly exo-/endo-thermic catalytic processes in tubular reactors", Chem. Eng. J., vols. 198-199, pp. 512-528, 2012. 
[35] C. Y. Zhao, "Review on thermal transport in high porosity cellular metal foams with open cells”, Int. J. Heat Mass. Tran., vol. 55, pp. 3618-3632, 2012.

[36] R. B. Chandran, R. M. De Smith, and J. H. Davidson, "Model of an integrated solar thermochemical reactor/reticulated ceramic foam heat exchanger for gas-phase heat recovery”, Int. J. Heat Mass. Tran., vol. 81, pp. 404-414, 2015.

[37] J.T. Richardson, D. Remue, and J.-K. Hung, "Properties of ceramic foam catalyst supports: mass and heat transfer", Appl. Catal. A: General, no. 250, pp. 319-329, 2003.

[38] D.A. Reay, "The use of polymers in heat exchangers", Heat Recovery Systems and CHP, vol. 9, no. 3, pp. 209-216, 1989.

[39] X. Chen, Y. Su, D. Reay, S. Riffat, "Recent research developments in polymer heat exchangers - A review”, Renew. Sustain. Energ. Rev, vol. 60, pp. 1367-1386, 2016.

[40] C. T'Joena, Y. Parkb, Q. Wangc, A. Sommersd, X. Hanc, A. Jacobib, "A review on polymer heat exchangers for HVAC\&R applications”, Int. J. Refrig., vol. 32, pp. 763-779, 2009. 
